\title{
Formalist and Instrumentalist Legal Reasoning and Legal Theory
}

One of the lasting contributions of the legal realist movement to American jurisprudence is the distinction between formalist and instrumentalist legal reasoning and legal theory. ${ }^{1}$ The legal realists described and attacked what they called the "formalism" of nineteenth-century jurisprudence. Their proposed reforms of judicial reasoning, when taken together, provide the paradigm for instrumentalism. ${ }^{2}$ Building upon the dichotomy between the legal realists' "instrumentalism" and nineteenthcentury formalism, a more modern group of legal historians has attempted to trace "formalism" and "instrumentalism" through American history. ${ }^{3}$ As a result of the combined efforts of the legal realists and these

I. On the legal realist movement generally, see G. GILMORE, THE AGES OF AMERICAN LAw (1977); W. RUMBLE, AMERICAN Legal REAliSM (1968); R. SUMMERS, INSTRUMENTALISM AND

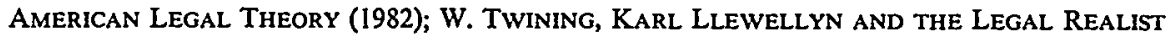
Movement (1974); Schlegel, American Legal Realism and Empirical Social Science: From the Yale Experience, 28 Buffalo L. Rev. 459 (1979); White, From Sociological Jurisprudence to Realism: Jurisprudential and Social Change in Early Twentieth Century America, 58 VA. L. REv. 999 (1972). For a legal realist's bibliography of legal realism, see Llewellyn, Some Realism About Realism, 44 HARv. L. Rev. 1222, 1257-59 (1931) [hereinafter cited as Llewellyn, Realism], continued in K. LLEWELLYN, PRÄJUdIZIENRECHT UND RECHTSPRECHUNG IN AMERIKA 120-22 (1931).

Major legal realist writings on judicial decisionmaking include J. FRANK, LAW AND THE MODERN Mind (1930); K. Llewellyn, The BRamble BuSH (1930); K. LIEWELIYN, THE COMMON LAW TRAdition: Deciding Appeals (1960) phereinafter cited as K. Llewellyn, The COMmON LAW Tradition]; Frank, Mr. Justice Holmes and Non-Euclidean Legal Thinking, 17 CoRNELl L. Rev. 568 (1932); Llewellyn, $A$ Realistic Jurisprudence-The Next Step, 30 ColUm. L. Rev. 431 (1930) [hereinafter cited as Llewellyn, Realistic Jurisprudence]; Llewellyn, Legal Tradition and Social Science Method: A Realist's Critique, in EsSAys ON RESEARCH IN THE Social ScIENCES (The Brookings Institute ed. 1931); Llewellyn, Realism, supra; Oliphant, A Return to Stare Decisis, 14 A.B.A. J. 71 (1928).

For a discussion of the legal realists' writings on judicial method as an attack on formalism, see generally J. ShKLaR, Legalism 93-99 (1964); R. SUMmers, supra; M. White, Social Thought in America: The Revolt Against Formalism (1957); Gilmore, Legal Realism: Its Cause and Cure, 70 YALE L.J. 1037 (1961).

2. The link between the legal realists and the term formalism is quite clear, but the story of how realism gave rise to the modern term "instrumentalism" is less clear. Thus Professor White notes throughout his article, supra note 1, that realism and instrumentalism are related, but he gives no account of the origins of the latter term. In ascribing to the legal realists the creation of the modern dichotomy between formalism and instrumentalism, this Comment refers much more to infiuence than to original conceptual contribution. In particular, this Comment adopts Professor Gilmore's conclusion that the theory that American judicial history can be divided into historical periods alternating between a formal and an instrumental style is largely the result of Professor Llewellyn's work, K. Llewellyn, The Common Law Tradrtion, supra note 1. See G. GiLMORE, supra note 1, at 11-13.

3. J.W. HuRST, LaW and the Conditions of Freedom in the Nineteenth Century UNITED STATES (1956) [hereinafter cited as J.W. HURST, CONDITIONS OF FREEDOM]; J.W. HURST, LAW AND SOCIAL Progress IN UNITEd STATes History (1960) [hereinafter cited as J.W. HURST, 
legal historians, the formalism/instrumentalism distinction has become an almost commonplace conceptual tool in the legal writer's workshop. ${ }^{4}$

Nevertheless, for all of its prominence, the formalism/instrumentalism distinction has proven elusive in recent jurisprudence. Although frequently employed, the distinction is formulated in many different ways. Modern writers cannot even decide whether the terms refer to contrasting styles of reasoning in legal cases-in other words, contrasting judicial or legal methods-or to differing theories about the nature of law or the nature of adjudication. This controversy leaves modern jurisprudence unable to appreciate fully the contribution and message of the legal realist movement and obscures the history and nature of shifting styles of American judicial reasoning.

This Comment will survey existing uses of the distinction and then attempt to provide an improved account of it. Part I will briefly describe the legal realists' attack on "formalism" and their distinction between formalism and instrumentalism, both as competing styles of judicial reasoning and as theories of law. Part II will show that the distinction as formulated by many realists has failed to bear intellectual fruit when put to work by legal historians, and that the most coherent of all the accounts of the distinction, provided by Professors H.L.A. Hart and David Lyons, has serious shortcomings. Part III will provide a new account of the distinction based in part on the "life" of a judicial rule or concept in analogical legal reasoning. The terms "instrumentalist" and "formalist" can be used in three related senses. Used in the primary sense, they are evaluative terms for critically analyzing the "age" of particular legal concepts used by a judge. Used in a secondary sense, the terms refer to styles of judicial reasoning characterized by a judge's tendency to use concepts of a particular "age." Finally, concepts of law can be called instrumentalist or formalist in a third sense when they lead a judge to reason in a way identified as instrumentalist or fornalist in the secondary sense. Part IV coinpares this new account to the competing account provided by Hart and Lyons. Part V shows that the new account captures the ineaning of the legal realists' criticism of nineteenth-century legal reasoning more completely than either the realists' own descriptions of formalism or the Hart-Lyons model. The new account also makes recent historical inquiries into the distinction more coinprehensible.

Social Progress]; Horwitz, The Emergence of an Instrumental Conception of American Law 1780 1820, 5 PERSPS. IN AM. HIST. 287 (1971); Nelson, The Impact of the Antislavery Movement upon Styles of Judicial Reasoning in Nineteenth Century America, 87 HARV. L. REV. 513 (1974).

4. See, e.g., H.L.A. Hart, The Concept of LAW (1964); R. Unger, KNowledge and Politics 88-100 (1975); Kennedy, Form and Substance in Private Law Adjudication, 89 HARV. L. REV. 1685 (1976); Kennedy, Legal Formality, 2 J. Legal STUD. 351 (1973); Note, Legal Theory and Legal Education, 79 YALE L.J. 1153 (1970). 


\section{The Legal Realist Critique of Formalism}

The legal realist movement of the 1920's and 1930 's $\mathrm{s}^{5}$ played a central role in formulating and bringing into prominence the formalism/ instrumentalism distinction. The realists' critique of formalism thus provides a useful and illuminating introduction to the controversy. To provide a broad overview of the movement, the legal realists can be divided into three groups of scholars: the judicial-reasoning group, the political reformist group, and the social-science group. ${ }^{6}$

\section{A. The Three Groups of Legal Realist Scholars}

The "judicial reasoning" group of legal realists attacked a supposedly prevailing natural law/formalist style of judicial reasoning left over from the nineteenth century. ${ }^{7}$ According to those legal realists whose charges are specific enough to withstand analysis, a central tenet of the formalist style was an overreliance on logical deduction in judicial decisionmaking. A formalist court was characterized by the realists as overly mechanistic, relying on existing legal rules and logical deduction to decide any and all cases presented to it. ${ }^{8}$ As a result of this excessive deductivism, legal rules became rigidly unchangeable, and law became

5. Of course, determining exactly when the legal realist movement "flourished" requires a definition of the membership of the movement. Thus, if one sees legal realism as but a facet of a broader movement in American instrumentalism, see R. SUMMERS, supra note 1, the period will be considerably longer than if one asserts that only post-World War I realists attempted to translate their ideas into concrete changes in educational practice and therefore alone deserve the honored title of "realist." See Twining, Pericles and the Plumber, 83 LAw Q. REv. 396, 407 (1967); Note, supra note 4, at 1157 .

The 1920's through 1930's period has been selected because legal scholars generally seem to agree on it, and because the most influential of the legal realists, Professors Jerome Frank and Karl Llewellyn, wrote their most influential realist works during this period. See authorities cited supra in note 1. The selection is for purposes of general discussion and is not intended to embody implicit judgments about which scholars were or were not legal realists. See discussion infra in note 24.

At a few points in this Comment some writers who are not usually or universally thought of as realists are alluded to for examples of legal realist thinking. This is done when the authors set forth in a concise way views that were influential in the realist school. Some remarks by Professor Llewellyn may help justify this approach:

The [legal realist] movement, the method of attack, is wider than the number of its adherents. It includes some or much work of many men who would scorn ascription to its banner. . . . Men more or less interstimulated-but no more than all of them have been stimulated by the orthodox tradition, or by that foment in the opening of the century in which Dean Pound took a leading part.

Llewellyn, Realism, supra note 1, at 1234.

6. The account of legal realism as a set of "groups" of scholars is based on the description provided by Schlegel, supra note 1, at 569-70. Professor Schlegel divides the movement into an empirical/scientific group, a political reformist group, and a philosophical group.

7. For a bibliography of this subgroup's works and a commentary thereon, see authorities cited supra in note 1 .

8. See, e.g., O.W. Holmes, The Common LAw (1881); Dickenson, Legal Rules: Their Function in the Process of Decision, 79 U. PA. L. REV. 833, 833-34 (1931). See generally G. 
inherently conservative. ${ }^{9}$ Thus, law could not adapt to the rapidly changing social circumstances of the early twentieth century. ${ }^{10}$ In other words, the legal realists asserted that formalists ignored the actual operation of legal rules in social settings.

In attacking formalism, the realists argued that logical deduction could solve very few concrete legal controversies. Thus some realists proposed and promoted nondeductive modes of judicial reasoning, emphasizing logical induction ${ }^{11}$ and the antilogical or alogical flavor of such reasoning. ${ }^{12}$ Other realists thought of mechanistic deduction as a mask behind which unbounded judicial discretion lurked; they argued that in order to avoid the pitfalls of this discretion, courts should rely on the legislature to make new laws. This insight led to the development of an antijudicial-activist branch of legal realism typified by the later writings of Professor Karl Llewellyn. ${ }^{13}$

The judicial-reasoning subschool of the legal realist movement helped to support the reforms espoused by another subschool-the largely liberal political-reformist group. ${ }^{14}$ This group pursued the "slightly left of center" political and pragmatic legal goals of the movement by attempting to bring existing legal doctrine, including securities law, civil procedure, sales law, constitutional law, antitrust, and tort law, into line with current social conditions. ${ }^{15}$

A third subschool of the movement, the social-science group, unified the political-reformist group and the judicial-reasoning group. ${ }^{16}$ The social-science group advocated incorporating the methodology of the

GILMORE, supra note 1, at 1-18; R. SUMMERS, supra note 1, at 154-56; M. WHite, supra note 1, at 15-17.

9. See, e.g., Dickenson, supra note 8, at 834; Patterson, Can Law Be Scientific?, 25 ILL. L. REV. 121, 130 (1930).

10. See, e.g., Llewellyn, Realistic Jurisprudence, supra note 1, at 453-54; Patterson, supra note 9, at 130-32; cf. J. FRANK, supra note 1, at 270-77.

11. See, e.g., B. Cardozo, The Nature of the Judicial Process 14-23 (1921). To some extent the realists' preference for induction is a result of their preference for particular rather than general rules. See, e.g., Llewellyn, Realistic Jurisprudence, supra note 1, at 459-60.

12. Realist writings concluding that judicial reasoning is alogical because based upon "hunches" include J. FRANk, supra note 1, at 121-26, 152-58; Frank, What Courts Do In Fact, 26 ILL. L. REV. 645, 653-55 (1932) (endorsing and expanding upon the theory of the judicial hunch found in Hutcheson, The Judgment Intuitive: The Function of the "Hunch" in Judicial Decisions, 14 CORNELL L.Q. 274 (1929)).

13. See, e.g., K. Llewellyn, The Common Law Tradition, supra note 1, passim.

14. For extensive citations to this group of scholars, see the bibliography by Llewellyn in Realism, supra note 1, at 1257-59.

15. Schlegel coins the phrase "slightly left of center," noting that "[o]ne of the characteristics of Realism as a movement was its slightly left of center politics," and he cites as support for this proposition the work of Douglas on securities law, Clark on civil procedure, Llewellyn on sales law, Hamilton on economic due process, Arnold on antitrust, and Borchard on the Federal Tort Claims Act and declaratory judgment. Schlegel, supra note 1, at 570 n.589.

16. For an in-depth study of the social-science group, see $i d$. 
emerging social sciences into the study of law in order to provide legal scholars with an understanding of law as it operated in its actual social context-"law in action."17 These scholars sought to "perform distinguished public service by assisting in the solution of the most pressing problem in the law by scientific study of all procedure in its functional, comparative, and historical aspects." 18 Such a study aimed at identifying the "working in practice" of legal rules. ${ }^{19}$

\section{B. Legal Realism and Formalism: The Origin of the Instrumentalist/ Formalist Distinction}

This brief description of the legal realist movement makes possible a standard account of both formalism as defined by the realists and instrumentalism as advocated by and embodied in the legal realist movement. According to the realists, formalism consisted of two views, or two mistakes, somehow related to each other:

(a) "deductivism," an overemphasis on logical deduction from extant rules seen as the sole content of law, leading to doctrinal rigidity; ${ }^{20}$

(b) legal conservatism, born out of (1) a disregard for law as actually operating in the legal system, and (2) a concomitant disregard for law as both a part of a larger social system and a tool for making that system more coherent, workable, and fair. ${ }^{21}$

The three subschools of legal realism focused on two central themes:

(a) deemphasis on logical deduction from existing legal rules ${ }^{22}$

and a willingness to bend or break those rules; ${ }^{23}$

(b) emphasis on law as a social phenomenon with social impact,

17. The phrase "law in action" was coined by Dean Roscoe Pound in Law in Books and Law in Action, 44 AM. L. REV. 12 (1910).

18. Schlegel, supra note 1, at 468 (citing Minutes of the Yale Law School, Feb. 25, 1976, and R. Hutchins \& C. Clark, A Program of Research in the Administration of the Law, Appendix A, at 1 (presented to the Yale Law School Feb. 25, 1926) (available in the Robert M. Hutchins papers in the Regenstein Library, University of Chicago)).

19. Id. (quoting Robert Maynard Hutchins, in Minutes of the Yale Law School, Feb. 25, 1926, and R. Hutchins \& C. Clark, A Program of Research in the Administration of the Law, Appendix A, at 3 (presented to the Yale Law School Feb. 25, 1926) (available in the Robert M. Hutchins papers in the Regenstein Library, University of Chicago)).

20. See authorities cited supra in note 8 .

21. See authorities cited supra in notes 9,10 ; $c$. R. Summers, supra note 1, at 138-39, 142-43, $143-44,146-54$.

22. See, e.g., Bingham, Legal Philosophy and the Law, 9 ILL. L. Rev. 98 (1914); Bingham, What is the Law? (pts. 1 \& 2), 11 MicH. L. REv. 1, 109 (1912) [hereinafter cited as Bingham, What is the Law? ]; Dickenson, supra note 8, at 834-36; cf. R. SUMMERS, supra note 1, at 142-43.

23. See, e.g., Cook, Scientific Method and the Law, 13 A.B.A. J. 303, 308 (1927); Llewellyn, Realistic Jurisprudence, supra note 1, at 52-53; Moore \& Callahan, Law and Learning Theory: $A$ Study in Legal Control, 53 YALE L.J. 1, 2-5 (1943); Oliphant, Facts, Opinions, and Value Judgments, 10 TEx. L. REv. 127, 137 (1932); cf. R. Summers, supra note 1, at 142-43; Pound, The Call for $a$ Realist Jurisprudence, 44 HARV. L. REV. 697, 70-08 (1931). 
and thus as a possible instrument for social change. ${ }^{24}$

The distinction the legal realists made between their proffered "realist" approach and the condemnable formalism of the nineteenth century gave birth to the modern distinction between formalism and instrumentalism. The legal realists defined in an influential way a jural evil called "formalism" and put forth a coherent antiformalism. Later writers called the legal realists' position "instrumentalism," and modern writers have elaborated on the controversy identified by the realists. ${ }^{25}$

While the modern distinction has had a major influence on historical scholarship, the realist formulation of the dichotomy manifests a peculiarity which will later prove illuminating. The legal realist account of formalism does not explain why legal realism was largely a negation of formalism. Actually, this curious symmetry is less than perfect; certainly other, noncorresponding features were ascribed to both legal realism and formalism. Nonetheless, this symmetry might initially lead one to suspect that formalism was a straw man created by the legal realist movement. Yet the American legal and legal-academic professions should have spotted such an intellectual straw man (or should have done so by now, some fifty years after the fact). A complete account of the formalism/instrumentalism distinction should explain the symmetrical opposition between the central tenets of both formalism and the legal realists' early version of instrumentalism.

The standard legal realist account also leaves unclear the question whether formalism and instrumentalism are styles of judicial reasoning or theories of law. A style of judicial reasoning is a logical, practical, or rational process by which a judge explicitly decides a legal case. Styles of judicial reasoning can be variously described as "legal methods,"26 "forms of argument," "processes of decision," "modes of reasoning," or

24. Although it is at least a marginally defensible task to try to separate and list, as does Schlegel, several "groups" of realist scholars, any attempt to summarize briefly exactly what "realism" meant is in principle impossible. Such a task, if conceived in purely historical terms, would never find the true meaning of realism. As Karl Llewellyn said of the realists, "A group philosophy or program, a group credo of social welfare, these realists have not. They are not a group." Lleivel. lyn, Realism, supra note 1, at 1256 (emphasis in original). Nevertheless, there are common points of departure, a certain "movement" or "method of attack" characteristic of a large group of scholars. Id. at 1234 .

The two-pronged characterization of legal realism set forth in the text is similar to Llewellyn's description of realism. Id. at $1234 \mathrm{n} .35,1238-41,1250-55$. It is also parallel to two of the seven elements that Dean Pound proposed to include in the new realist jurisprudenee: "[a] functional attitude, i.e. study not only of what legal precepts and doctrines and institutions are, and how they have come to be, but of how they work," and "[r]ecognition of the significance of the individual case" as against the "absolute universalism of the last century." Pound, supra note 23, at 710.

25. See discussion supra in note 2.

26. R. SUMmERS, supra note 1 , at $136-75$. 
"types of justification."27 A theory of law, in contrast, is a view or set of views about the nature or function of law, the legal order, or a particular legal institution or set of institutions. The distinction between styles of reasoning and theories of law is parallel to one that can be drawn in moral philosophy between the actual process by which a moral decision is made and a philosophical explanation of that process and its significance. ${ }^{28}$

The distinction between styles of reasoning and theories of law has played an important but not entirely clear role in the formalism/instrumentalism controversy. The legal realists, for example, associated formalism with a strictly logical or deductive and quasi-automatic reasoning style, ${ }^{29}$ and with theories of law including natural law and judicial conservatism. ${ }^{30}$ Legal realism, or instrumentalism, was associated with a judicial method less deferential to precedent and more inclined to construe rules narrowly, and with a theory of law as an instrument of social change. $^{31}$ The legal realists seemed to conceive of formalism as involving both a theory of law and a judicial reasoning style, and so the realist alternative offered both in its place. Yet the realist account does not explain how a formalist or instrumentalist reasoning style interacts with, is influenced or determined by, or is otherwise related to formalist or instrumentalist legal theories. This deficiency in turn makes an accurate assessment of the conceptual coherence and importance of the legal realist movement difficult.

The legal realists' characterization of formalism and their proposed alternative determined the shape of the formalism/instrumentalism controversy in later legal scholarship. Part II examines legal historians' efforts to explore the formalism/instrumentalism distinction and shows that, although initially plausible, the standard legal realist account has not enabled these historians to isolate and identify either shifts from one of these reasoning styles to the other or the links between these reasoning styles and their corresponding theories of law.

27. These phrases are collected in Paine, Formalism v. Instrumentalism: Dissolving the Dichotomy, 1978 Wis. L. REV. 997,999 n.7.

28. It should be noted that Paine uses the terminology "conceptions of law" to denote theories of law. Id. at 999. This Comment will adhere to terminology that more closely parallels the classical distinction between practical and theoretical reasoning. See ARISTOTLE, Nichomachean ETHICs Book 1, 1140a24-b30, 1141a9-b24, passim (M. Ostwald trans. 1962).

29. See authorities cited supra in note 8.

30. For the charge that natural law and formalism are somehow connected, see Dickenson, supra note 8, at 836 , and authorities cited id. at $836 \mathrm{n} .9$. For the charge that formalism was in some sense conservative, see, for example, Oliphant, supra note 1, at 76. See also authorities cited supra in note 9.

31. See, e.g., Cohen, On Absolutisms in Legal Thought, 84 U. PA. L. REV. 681 (1936); Llewellyn, Realistic Jurisprudence, supra note 1, at 459-60. See generally R. SuMMERS, supra note 1, at 144-46. 
II

Post-Legal Realist Historiography: The Search For FORMALISM AND INSTRUMENTALISM

A group of historians adopting all or a part of the legal realists' understanding of the formalism/instrumentalism distinction, and relying on scholarly groundwork laid by Professor Willard Hurst, ${ }^{32}$ have described the history of American judicial reasoning styles in terms of shifts from formalism to instrumentalism and vice versa. But an examination of some of these authors' influential works shows that the historical evidence upon which they base their claims fails to document any such shift. In fact, two such historians, Professors Morton Horwitz and William Nelson, seem unable to identify formalism or instrumentalism as styles of judicial reasoning.

\section{A. Horwitz's Search for a Transition from Instrumentalist to Formalist "Conceptions" of Law}

Morton Horwitz has recently analyzed the emergence of an instrumental theory of law-which Horwitz calls an instrumentalist "conception" of law-from 1780 to $1820 .{ }^{33}$ Although Horwitz focuses on evidence of an instrumental theory of law, it is quite clear from the outset that he also wishes to show something about the legal method of American judges: how they framed legal doctrines, made legal arguments, and so on. ${ }^{34}$ However, Horwitz fails to show how differing theories of law, which he characterizes as instrumentalist or formalist, affected the judicial reasoning process. This is a critical shortcoming, because instrumentalism and formalism as theories of law diminish in significance if they are not shown to have influenced the actual decisionmaking process in legal cases. For if formalism and instrumentalism as theories of law have no effect upon the development of law, they appear to be little more than trends in the reflections or abstractions about law made by judges and other legal officials.

Horwitz asserts that in the revolutionary period, American judges thought of common law rules not as instruments for social change but as a fixed body of doctrine derived from "natural law." 35 The purpose of law was to produce a fair result between private litigants in individual

32. See, e.g., J.W. HuRST, Conditions of Freedom, supra note 3; J.W. HuRSt, Social PROGRESS, supra note 3.

33. Horwitz, supra note 3.

34. Thus, in his opening statement Horwitz speaks of the shift from instrumentalism to formalism as a shift from simply applying fixed doctrine in a particular case in order to achieve a fair result, to analyzing common law rules functionally or purposively. Id. at 287; see also id. at 287-91.

35. Id. at $287,291$. 
cases. $^{36}$ But Horwitz does not link this formalist conception of law to any feature of actual judicial method, either by citing to particular cases or arguing for a more abstract connection. A promising thesis in this connection is Horwitz's assertion that natural-law theory caused jurists to adopt a strict doctrine of precedent: natural law was immutable, and judges were not to disregard or change immutable rules. ${ }^{37}$ In providing evidence of a "strict" doctrine of precedent Horwitz succeeds in showing only that some judges held as a part of their notion of proper adjudication-as part of their theory of law-that precedent ought to be strictly followed. He does not attempt to produce evidence that judges followed precedent strictly in concrete cases in a manner that affected their reasoning styles. ${ }^{38}$

According to Horwitz, this period of natural law/formalism was followed by a period of instrumentalism. By the beginning of the nineteenth century, jurists were using common law rules to bring about social changes, in particular economic changes. Private law was now conceived of as legislated by judges, and thus judges consciously analyzed common law rules to discover their policy implications in the same way that legislators studied statutes.

Horwitz sets for himself the task of explaining

why it was only in the nineteenth century that the common law took on its innovating and transforming role in American society. This in turn forces us to ask whether an explanation for this fundamental shift in the conception of law between 1780 and 1820 can be found in more general changes in the political theory of the period. ${ }^{39}$

He then describes postcolonial instrumentalism as consisting chiefly of a functional or purposive analysis of common law rules and a self-conscious use of common law rules as creative instruments for social change. ${ }^{40}$ Horwitz argues that a view of law as a product of the popular will displaced the earlier natural-law view. ${ }^{41}$ One sign of this shift in thinking was a distinctly postrevolutionary conviction that common law was both uncontrollable and unpredictable, ${ }^{42}$ manifested in a new hostility to the federal common law of crimes. ${ }^{43}$ As Horwitz puts it, "as [ju-

36. Id. at 287.

37. Id. at 297-98.

38. Id. Horwitz cites dicta in a Supreme Court opinion and two treatises stating that all law was discovered, not made. However, such statements could justify a merely verbal adherence to precedent coupled with an expansive or fiexible interpretation of precedents governing concrete cases. What Horwitz fails to show is that the natural law theory caused judges to follow existing rules even though the rules seemed unjust or irrational as applied to the cases.

39. Id. at 291.

40. Id. at 290-91.

41. Id. at $310-13$.

42. Id. at 305 .

43. Id. at 299. 
rists] sought to redefine the basis of legal obligation in terms of popular sovereignty, they tended to assert the ultimate primacy of the legislature and of statute law. The result was that the original natural law foundation of common law rules began to disintegrate."44

Horwitz's evidence that instrumentalism emerged as a theory of law is impressive. Once again, however, he fails to link the new popular-will/ instrumentalist theory to any distinct style of judicial reasoning. He does not explain how the shift in theories influenced decisionmaking in particular cases. ${ }^{45}$

Horwitz does show, however, how theories of law might have

44. Id. at 310 . Even at the level of theories of law, Horwitz's account is incomplete. He offers the adoption of a popular-will theory of law to explain why jurists with the natural law/formalist understanding of common law shifted to the new instrumentalist view. Yet there is no incompatibility between the natural law view and the newer popular-will theory of sovereignty. Law can find its source in God or nature whether judges or the people (through the legislature) discern and implement the law. Moreover, judicially made "natural law" can be explained in "popular-will" terms as judicial acquiescence to popular social practices.

Indeed, Horwitz produces historical evidence of eminent postcolonial jurists who thought natural law was reconcilable with a popular-will theory of sovereignty. Id. at 312-13. Scholars like James Wilson argued that custom was in fact legitimate because it rested on the firm foundation of acquiescence by many people over time:

"How was a custom introduced? By voluntary adoption. How did it become general? By the instances of voluntary adoption being increased. How did it become lasting? By voluntary and satisfactory experience, which ratified and confirmed what voluntary adoption had introduced. In the introduction, in the extension, in the continuance of customary law, we find the operations of consent universally predominant."

Id. at 312 (quoting THE WORKS of JAMES WILSON (R. McCloskey ed. 1967)). Thus, although Horwitz asserts that "[t]he problem of fitting the common law into an emerging system of popular sovereignty became the central task of judges and jurists at the turn of the century," $i d$. at 313 , it is unclear whether the emergence of such a conception of law as a product of human will conflicted with or compelled a rejection of the earlier, so-called "formalist" appronch to common law.

Moreover, a popular-will theory does not seem conceptually related to the instrumentalism Horwitz describes - a willingness to mold legal rules to fit social circumstances. Nothing about the idea of law as a product of human will dictates that laws, once produced by human will, must be open to quick judicial change whenever judges perceive that social conditions mandate the change. In fact, a judge might well decide that because law is a product of popular will and because his fiats are not, a popular-will theory of legitimacy commands that he must obey all legal rules in a "formalist" manner.

45. Horwitz also claims that the new theory of law produced certain effects in actual legal decisionmaking: 1) a narrower role for the jury; 2) a decline in the significance of technicalities in determining the outcome of cases; 3) less analysis in terms of a static system of common law writs; and 4) less analogizing to inherent categories of the legal system. Id. at 322-25. The last three of these relate to judicial reasoning style. However, to the extent that Horwitz's evidence goes beyond evidence of an instrumentalist theory of law, it also goes beyond judicial reasoning style to a substantive instrumentalist reassessment of the law. Where Horwitz shows that technicalitics, common law writs, and the inherent categories of the law are disregarded in practice and not merely in theory, his evidence also shows jurists realizing that the law was out of date. That evidence includes: first, the characterization of the older rules of pleading as a product of "an age when the minds of men were fettered in forms"; and second, the argument for a new rule on corporate liability in tort on the ground that corporations had become much more common. Id. at 325. To this extent, Horwitz's analysis of "instrumentalism" begins to exemplify the account of instrumentalism put forth infra in Part III. 
shifted from a formalist group of theories to an instrumentalist group. He even begins to explain how these two groups of theories were held together internally and were related to each other. For example, Horwitz explains that if laws are conceived of as a product of natural law, then legal rules must be strictly followed because natural laws should not be changed. ${ }^{46}$ Thus, a theory of natural law and a theory that precedent should be strictly followed are at least prima facie conceptually related. Horwitz succeeds in showing that colonial judges thought law was the product of natural law, but that as economic growth occurred, judges began to view law both as an instrument of social change and as a product of popular will. But Horwitz does very little to explain why one should think of formalism and instrumentalism as distinct judicial styles.

Absent an account of how and why formalism and instrumentalism affect the way that particular legal cases are decided, there is no connection established between these theories and the daily acts of these legal officials. Without such a connection, formalism and instrumentalism seem to be of minimal importance as jurisprudential phenomena: they amount to no more than trends or tendencies in dicta, law treatises, and works by statesmen on the subject of how law fits into the grand scheme of things. Such abstractions do not produce much concern unless they affect the path of law.

\section{B. In Pursuit of Instrumentalism and Formalism: William Nelson on Judicial Reasoning Styles}

William Nelson's analysis of mid- to late-nineteenth-century judicial reasoning presents another attempt to identify and contrast formalist styles of judicial reasoning. ${ }^{47}$ Nelson also attempts to document and explain a shift from instrumentalism back to formalism beginning in the middle of the nineteenth century.

Nelson adopts Horwitz's definition of instrumentalism as "a conception of law as a means to the attainment of an end"; in the case of nineteenth-century instrumentalism, the end to be attained was "economic growth." 48 At least initially, Nelson clearly distinguishes theories of law from judicial reasoning styles, and thus identifies two different kinds of instrumentalism. The first views the entire legal system, "in the sense of entire bodies of law like the law of contracts," as a means to an end. The second is instrumentalism that views "the rulemaking that occurs in individual adjudications" as a means to an end. ${ }^{49}$ Focusing on the second notion, Nelson proposes to identify and explain "a shift in the style of

\footnotetext{
46. Id. at 296-97.

47. Nelson, supra note 3.

48. Id. at 514 .

49. Id. at 515 .
} 
judicial reasoning in individual cases-a shift from a style in which judges explicitly asked themselves whether a proposed rule would promote economic growth to a style in which judges asked whether a proposed rule was consistent with an existing body of doctrine."50

Nelson labels the latter style of judicial reasoning "formalism." Formalists, he claims, think that rules of law decide cases and that policy decisions are for the legislature, not for the courts. For the formalist, moreover, results follow " in deductive form with an air or expression of single-line inevitability' from the mere application of existing doctrine." 1 Thus, formalist judges "saw their task as . . . the preservation of the logical structure of the rules and fundamental principles of the law"s2 and felt obligated to harmonize particular decisions with past precedents. ${ }^{53}$ Thus, Nelson's description of formalism contains two familiar elements-deductivism and a strict doctrine of precedent-and adds the notion that alteration of existing doctrine is the province not of the courts, but of the legislature.

Drawing on the writings of early nineteenth-century jurisprudential theorists and treatise writers, Nelson shows that an impressive number of these authorities viewed law as a force to be harnessed to promote economic growth. ${ }^{54}$ Nelson gives numerous examples of cases rejecting "ancient authorities" and purporting to look "to the circumstances of the country" to formulate legal rules. ${ }^{55}$ In other words, these cases articulate instrumentalist legal theories. But when Nelson examines actual case law to isolate an instrumentalist style of judicial reasoning, his evidence is less conclusive.

Nelson attempts to document a judicial tendency in the early nineteenth century to reject arguments for "deduc[ing] results in a formalistic style from fundamental premises about the individual rights of man."56 He cites as a chief example the Supreme Court's decision in Charles River Bridge v. Warren Bridge ${ }^{57}$ which, according to Nelson, adopted an instrumentalist style of judicial reasoning and rejected a formalist style. ${ }^{58}$ Nelson cites as other examples state court contract cases and landmark

50. Id. at 516.

51. Id. at 514 (quoting K. Llewellyn, The Common LAw Tradition, supra note 1, at 38).

52. Id. at 515 .

53. Id. at $515 \mathrm{n} .12$.

54. Id. at 519-21.

55. Id. at 520-23. However, in an article rebutting Nelson, Professor Harry Scheiber has pointed out numerous examples of the reception of ancient doctrines and precedents during the same period. Scheiber, Instrumentalism and Property Rights: A Reconsideration of American "Styles of Judicial Reasoning" in the 19th Century, 1975 WIS. L. REV. 1.

56. Nelson, supra note 3 , at 522-23.

57. 36 U.S. (11 Pet.) 419 (1837) (holding that owners of a toll bridge built pursuant to a legislative charter could not enjoin the construction of a free bridge along a proximate route).

58. Nelson, supra note 3 , at 523-25. 
Supreme Court decisions that apparently affirmed the use of law to promote economic development. ${ }^{59}$

Professor Scheiber has argued that while instrumentalist judicial reasoning may have indeed existed in the early nineteenth century, strong evidence indicates that it persisted into the late nineteenth century. Scheiber concludes that the new formalist style, if it did appear, coexisted with a persisting instrumentalist mode of judicial reasoning. ${ }^{60}$ In addition, Scheiber suggests that even as theories of law, instrumentalisin and forinalism coexisted in the late nineteenth century. Due process decisions, pro-state inercantilist decisions, and decisions "often drainatically" abridging vested property rights for the sake of the states' economic growth goals all illustrate that the instrumentalist theory of law as a means to economic growth persisted, even after $1865 .^{61}$ Scheiber's evidence suggests that Nelson has failed to show that instrumentalism died at all.

Nelson also attempts to document a rise in formalism during the mid-nineteenth century. Nelson's thesis is that the mineteenth-century antislavery movement and its rhetoric of "higher law" produced a new formalism. According to Neison, "when instrumentalism was at the height of its influence, antislavery jurisprudence was revivified, and with it there arose ideas about morality which had jurisprudential implications inconsistent with the premises of instrumentahism." 62

If Nelson is correct, he should be able to show why any appeal to higher law is not only evidence of a formalist theory of law, but also a sure sign of a formalist (or at least an anti-instrumentalist) style of judicial reasoning. Nelson's account of antislavery jurisprudence and its preCivil War judicial skirmishes with instrumentahism provides no such demonstration. This is not surprising, given that the "three strands of American thought" Nelson identifies as the source of antislavery jurisprudence-religion, transcendentahisin, and human rights-contain attributes of natural law theory, but no hint of deductivism or strict adherence to precedent. ${ }^{63}$

59. See id. at 524-25 (discussing Gibbons v. Ogden, 22 U.S. (9 Wheat.) 1 (1824); Swift v. Tyson, 41 U.S. (16 Pet.) 1, 9 (1842); and Cooley v. Board of Wardens, 53 U.S. (11 How.) 298 (1851)).

60. Scheiber, supra note 55 , at 12.

61. Id. at 12-17.

62. Nelson, supra note 3 , at 525 .

63. The first strand of American thought in antislavery jurisprudence was religion, "particularly radical evangelical religion"--more specifically, "the ancient notion that there exists a higher law in the form of ultimate principles of morality, from which all human law is derived and with which all human law must be consistent." Id.

This strand of thought says nothing about either deductivism or a strict doctrine of precedent; in fact, it is hard to see why one could not characterize such a theory of law as "instrumentalist" in the sense of secing law as a means to an end. Antislavery advocates, like all good natural law 
In fact, higher law antislavery rhetoric often attacked existing precedents by arguing that no government could abridge man's inherent freedom and independence. ${ }^{64}$ The same human rights tradition manifested a similar hostility to positive law that encroached upon individual property rights guaranteed by natural law. ${ }^{65}$ Many of the cases Nelson uses to describe nineteenth-century antislavery "formalism" in fact show judges who wholly disregarded existing law in order to bring about justice in accordance with higher law. James Kent and Joseph Story appealed to a higher law doctrine to strike down legislative acts that involved takings of property, "even if the acts violated no written constitutional rule." 66 Similarly, Nelson cites state court opinions supporting the inherent pow-

thinkers, did not identify positive law with natural law, for they admitted the possibility of morally iniquitous laws. Their dedication to the immutability of natural law need not have produced a similar feeling that positive law was immutable. In fact, radical evangelists could well have believed that positive law and precedent not in accordance with higher law had to be disregarded. Thus, as Nelson reports, "[They] also knew that rules enacted by human institutions which were not in accord with [their] understanding of eternal law were not law, 'for none but the Law-giver himself . . . [could] make exceptions to his own laws." "Id. at 526 (quoting LeTTERS of THE REV. DR. BeEcher aNd Rev. Mr. NetTleton on the "New Measures" in Conducting Revivals of RELIGION 93 (1828)). Indeed, it is not too difficult to characterize this sort of thinking as instrumentalist-positive law is a means directed towards the end of aligning human government with the law of nature or law of God. For example, Nelson cites a string of state court cases invalidating legisla. tive enaetments on the ground that these enactments were contrary to the fundamental principles of justice. Id. at 532 n.124.

One would therefore expect that because radical evangelists saw the law as instrumental in bringing about higher law on earth, they would have been particularly willing to disregard both precedent and deduction when such sources yielded a substantive result with which they strongly disagreed. Far from unifying Nelson's account of formalism, this "strand" of American thought opens up the possibihity that antislavery jurisprudence was antideductivist, counterprecedential, and thus, in Nelson's own terms, instrnmentalist.

Nelson also attempts to find formalism in the second strand of thought, American transcendentalism. Id. at 526-27. Again, however, transcendentalists would presumably be opposed to law used as a means to economic ends; but in favoring law as a means to moral or transcendentalist ends, they would surely be instrumentalist. In cases involving the fugitive slave laws, transcendentalists disagreed with so-called instrumentalist judges as to whether law should further morality or further economic efficiency. Yet this fact simply shows that transcendentalists favored morality over economic efficiency.

The third strand of antislavery jurisprudence consists of 18th-century human rights traditions according to which "all men possessed certain rights that neither government nor other men could infringe." Id. at 528-29. These theories, especially those concerning individual rights to property, could easily be characterized as instrumentalist, and could quite consistently espouse the use of law to protect these human rights.

In summary, none of the three strands of thought underlying antislavery jurisprudence compels deductivism or a strict doctrine of precedent, and all three point to an "instrumentalist" theory of judicial reasoning. It seems highly unlikely, therefore, that a deductivist, anti-instrumentalist scliool of thought strongly committed to stare decisis could emerge from these three strands.

64. Id. at 529-30 (citing Commonwealth v. Jennison (Mass. 1783), reprinted in W. CusHING, Notes of Cases Decided in the Superior and Supreme Judicial Court of MassachuSETTS, 1772-1789, at folio 35a (1789); and St. George Tucker in 2 BlACKSTONE's COMMENTARIES App. at $41-42$ (St. G. Tucker ed. 1803)).

65. Id. at 530 .

66. Id. 
ers of the judiciary, "independent of constitutional provisions, to invalidate legislative enactments as contrary to fundamental principles of justice." 67

Nelson also details a series of federal and state cases in the 1840's and 1850's that brought instrumentalism and antislavery formalism into conflict. But repeatedly in these cases the judicial supporters of slavery took a "formalist" position against the "instrumentalist" extraprecedential arguments of the opponents of slavery. Thus, when Chief Justice Lemuel Shaw of Massachusetts denied a writ of habeas corpus to a fugitive slave, ${ }^{68}$ antislavery advocates concluded that the decision simply was not law, because it violated the natural rights of man. ${ }^{69}$ Conversely, the famous Dred Scott case ${ }^{70}$ relied on precedent and legislative history, supposedly the characteristic tools of formalism, to sweep away antislavery arguments. ${ }^{71}$ In short, Nelson cannot isolate any feature of formalism in the higher law antislavery jurisprudence, except of course for the commitment to "higher law"-itself a theory of law. Like Horwitz, Nelson seems unable to find any historical evidence of a reasoning style answering to the name of instrumentalism or formalism.

Nelson's last attempt to document a rise in formalism invokes the "law-as-science" jurisprudence of the nineteenth century. The writings of Christopher Columbus Langdell exemplify this approach. ${ }^{72}$ Nelson, however, provides no evidence that this law-as-science notion, even if it did seep into nineteenth-century jurisprudence, was ever synthesized with higher law doctrines. Nelson simply refers to two treatise writers, Thomas Cooley and John Dillon, who used "higher law language" in court cases and later wrote treatises on law-as-science. But Nelson provides no evidence that these two notions are at all related, even in the writings of these two men. ${ }^{73}$ Nor does he show that the law-as-science

67. Id. at $531 \mathrm{n} .134$.

68. Id. at 540 (citing The Latimer Case, 5 LAw REP. 481 (Mass. 1843)).

69. Id. at 541 .

70. Scott v. Sandford, 60 U.S. 393 (1857).

71. Id.

72. See generally C. LANGdell, A Selection of Cases on the LAW of Contracts (2d ed. 1879). According to Nelson, this new "law-as-science" school produced legal scientists who emphasized doctrinal interactions, consistency, and reconciliation or careful rejection of all existing cases. Nelson, supra note 3, at 560-61. Nelson claims both that this school of jurisprudence had a significant impact on judges and legal decisions and that it blended with the higher law doctrines of antislavery jurisprudence to create 19th-century formalism. Id. at 563. Again, however, the evidence Nelson provides is inconclusive. To show the influence of the law-as-science school in late 19th-century jurisprudence, Nelson cites only two rulings, one by a judge who belonged to a law faculty and wrote a treatise espousing the theory of law-as-science. Id. at 565, $565 \mathrm{nn} .357-58$.

73. Nelson, supra note 3 , at 565 . Further, Nelson's main thesis that formalism had no significant 19th-century antecedents has been questioned by Professor Harry Scheiber. Scheiber points out that just as instrumentalism was alive and well in the late 19th century, formalism was alive and well in the early 19th century. Accepting arguendo Nelson's definition of formalism, Scheiber points out 
theory contributed to an instrumentalist reasoning style in particular cases.

\section{Some Implications of Post-Legal Realist Historiography}

As shown above, Horwitz's article helps make formalism as a theory of law conceptually coherent. However, Horwitz fails to show how formalism affected judicial reasoning, and thus he makes the legal realists' efforts to warn against formalism's effects on judicial lawmaking appear groundless. In addition, Horwitz fails to find an instrumentalist style of reasoning.

Nelson also fails to document either a formalist or an instrumentalist style of judicial reasoning. In fact, he shows supposedly formalist higher law thinkers adopting an instrumentalist disregard for precedent and supposedly instrumentalist judges adhering to precedent in a strikingly formalistic way. Formalism and instrumentalism do not seem to have existed as opposing judicial styles, and neither Horwitz nor Nelson convincingly documents the transition from one of these judicial styles to the other.

The legal realists' account of formalism thus appears to lack foundation in the history of judicial reasoning. Studies by legal scholars utilizing the realist-created formalism/instrumentalism dichotomy have failed to show that these two styles of judicial reasoning ever existed as competing forces in American jurisprudence. Viewed in this light, the "formalism" and "instrumentalism" Nelson and Horwitz have found appear to be nothing. more than contrasting statements about law in law treatises and contrasting types of dicta in judicial opinions.

\section{The Hart-Lyons Model of Instrumentalism and Formalism}

Before concluding that no account of the formalism/instrumentalism distinction successfully distinguishes the two competing styles of reasoning, it is necessary to examine the most conceptually coherent

that to test Nelson's thesis generally one must look at early 19th-century cases in the same substantive area of law as the late 19th-century antislavery opinions. One should thus consider

pre-1850 cases bearing upon personal liberty-not only criminal cases but, for example, writings and judicial decisions upon insolvency and imprisonment for debt. Should such an inquiry produce evidence that the pre-1850 courts were adopting "ancient precedents," higher-law doctrines, and notions of inalienable rights-much as they did in adjudicating riparian and eminent domain questions-it would cast doubt on the entire validity of Nelson's view of post-Civil War jurisprudence.

Scheiber, supra note 55, at 6 (emphasis in original).

Scheiber himself indicates that such evidence exists in the "inalienable rights of man" notions manifested in civil and criminal cases involving blacks in the pre-Civil War South. Nelson, then, cannot show that formalism arose only in the late 19th century, for the natural law rhetoric that Nelson has found persisted throughout the 19th century. Id. at $6 \mathrm{n} .27$ (citing Nash, The Texas Supreme Court and Trial Rights of Blacks 1845-1860, 58 J. AM. HIST. 622 (1971)). 
account yet provided-the Hart-Lyons model. H.L.A. Hart has argued that formalists and some of the more radical legal realists can be understood as taking opposing but equally incorrect views about the extent of "open texture" in legal rules-the extent to which legal rules are by their very nature indeterminate. ${ }^{74}$ Professor David Lyons has argued that Hart's model substantially explains what is significant in the legal realists' version of the formalism/instrumentalism controversy. ${ }^{75}$ To appreciate the Hart-Lyons model, it is necessary to understand three Hartian concepts-open texture, formalism, and rule skepticism.

\section{H.L.A. Hart on Open Texture, Formalism, and Rule Skepticism}

H.L.A. Hart has argued that rules, standards, or principles designed to serve as the main instrument of social control in any large group must predominantly refer to general classes of persons, acts, things, and circumstances, rather than to particular persons, acts, and so on. ${ }^{76}$ The modern legal system uses two principal devices to effectuate social control-statements of legislation and statements of precedent. Both types rely on general terms to define the classes to which the statements apply. ${ }^{77}$ Statements of legislation, which must give notice of the specific situations they are meant to cover, must use many such terms; statements of precedent, because formulated on a case-by-case basis to deal with more concrete factual situations, may use very few. In either case, the inherent indeterminacy of the general, class-defining terms limits the extent to which a legal rule or concept can guide definitively its subsequent applications. ${ }^{78}$

These general terms must have a settled core of meaning; in other words, there must be a defined set of cases to which the terms apply and to which the rule therefore applies. In addition, there are cases in which application of the rule is uncertain. In these cases the general language can only serve as a general guide as to how to apply the rule; it serves much the same function as the authoritative example of a situation to which the rule unquestionably applies.

74. Hart's initial interpretation of the formalism/instrumentalism dichotomy appears in H.L.A. HART, supra note 4, at 121-50 (1964), and is supplemented in Hart, American Jurisprudence through English Eyes: The Nightmare and the Noble Dream, 11 GA. L. REV. 969 (1977). See also Hart, Positivism and the Separation of Law and Morals, 71 HARV. L. REV. 593 (1958) [hereinafter cited as Hart, Law and Morals].

75. Lyons, Legal Formalism and Instrumentalism-A Pathological Study, 66 CORNELL L. REV. 949 (1981).

76. H.L.A. HART, supra note 4, at 121. Note that this feature alone assures deduction a major role in Hartian legal reasoning-specifically, the deduction from the legal rule as one premise, and from the statement of the recognition of a specific person, act, thing or circumstance as an instance described by the rule as a second premise, to the conclusion that the law applies.

77. Id.

78. Id. at 123. 
Hart describes the functions that the general language must serve in such cases with an example of a legal rule forbidding vehicles in a park:

This [language] may be used in much the same way as a precedent, though the language of the rule will limit the features demanding attention both more permanently and more closely than precedent does. Faced with the question whether the rule prohibiting the use of vehicles in the park is applicable to some combination of circumstances in which it appears indeterminate, all that the person called upon to answer can do is to consider (as does one who makes use of a precedent) whether the present case resembles the plain case "sufficiently" in "relevant" respects. The discretion thus left to him by language may be very wide; so that if he applies the rule, the conclusion, even though it may not be arbitrary or irrational, is in effect a choice. ${ }^{79}$

When establishing this legal rule, the legislature intended to exclude from the park such vehicles as cars, buses, and motorcycles. This legislature initially made the judgment that peace and quiet in the park were to be maintained at the cost of excluding vehicles. ${ }^{80}$ But there are possible future fact situations of which the legislature was ignorant, and thus policy choices to be made on which the legislature was silent. Thus the rule says nothing about vehicles the legislature did not contemplate, such as toy motor cars. The rule's indeterminacy allows the legal official deciding cases under the rule to resolve the toy auto case as a novel case in light of present policy considerations that the legislature could not have considered when the rule was first formed. Hart calls this built-in indeterminacy of a legal rule its "open texture."81

According to Hart, the phenomenon of open texture raises the possibility that a legal actor can display two vices in his attitude towards rules-formalism or rule skepticism. A legal actor is a formalist when that actor decides all the cases, or proposes that others decide cases, as if there were no open texture to the rule. Thus a formalist refuses to recognize that "he is in the area of the penumbra and is not dealing with the standard case." 82 This attitude produces a method of judicial reasoning that is doctrinally rigid and overly conceptualistic:

79. Id. at 124. Although Hart emphasizes the discretionary character of deciding hard cases in the area of open texture, he does insist that the process is not without guidance from the law:

[The decisionmaker] chooses to add to a line of cases a new case because of the resemblances which can reasonably be defended as both legally relevant and sufficiently close. In the case of legal rules, the criteria of relevance and closeness of resemblance depend on many complex factors running through the legal system and on the aims or purpose which may be attributed to the rule. To characterize these would be to characterize whatever is specific or peculiar in legal reasoning.

Id. at 124; cf. Hart, Problems of Philosophy of Law, in 6 ENCYClopedia OF PHILOSOPHy 264, 269 72 (P. Edwards ed. 1967).

80. H.L.A. HART, supra note 4 , at 126 .

81. Id. at 124 .

82. Hart, Law and Morals, supra note 74, at 610. Hart uses the term "penumbra" to refer to the area of open texture in a legal rule. 
To [ignore open texture] is to secure a measure of certainty or predictability at the cost of blindly prejudging what is to be done in a range of future cases, about whose composition we are ignorant. . . . We shall be forced by this technique to include in the scope of a rule cases which we would wish to exclude in order to give effect to reasonable social aims, and which the open textured terms of our language would have allowed us to exclude, had we left them less rigidly defined..$^{83}$

The opposite jurisprudential vice is rule skepticism. In all its varieties, rule skepticism exaggerates the extent to which there is open texture in a rule. The relevant form of rule skepticism for our purposes is that relating to judicial decisionmaking. ${ }^{84}$ The rule skeptic of the judicial decision asserts that there is little or no settled core to a legal rule, but only open texture. Therefore, judicial discretion is unlimited. " "[S]o far as the courts are concerned, there is nothing to circumscribe the area of open texture: so that it is false, if not senseless, to regard judges as themselves subject to rules or 'bound' to decide cases as they do."

\section{Lyons on the Hart Model}

Hart's understanding of formalism suggests that to the extent legal realists battled formalism, their contribution to jurisprudence was limited to illuminating the extent to which legal rules have open texture. But Hart's strongest claim is that much of American jurisprudence can be understood in terms of his formalism and rule-skepticism model. Hart does not make the more powerful claim that the opposition between instrumentalism and formalism in general, or the legal realists' opposition to nineteenth-century formalism in particular, should be understood solely as a dispute between formalists and rule skeptics over the extent of open texture in legal rules. ${ }^{87}$

Professor David Lyons, however, does make this further historical claim. Lyons claims that the vice the legal realists called formalism was nothing more than commitment to the view that law rooted in authoritative sources has no "gaps" in it. ${ }^{88}$ If law has no gaps-in Hartian terms, if legal rules have no open texture - then every case can be decided simply by applying the relevant legal rule and deducing therefrom the legal decision. Lyons calls this view the "formalistic model" of legal justifica-

83. H.L.A. HART, supra note 4 , at 126-27.

84. Id. at 135. Hart also discusses and criticizes more extreme forms of rule skepticism. Id. at 132-35.

85. Id. at 135 .

86. Id.

87. It would be incorrect to assert that this is all that Hart thinks the legal realists had to say. For example, Hart attributes to one legal realist the achievement of elucidating the distinction between the internal and external points of view with respect to legal rules. See id. at 244.

88. Lyons, supro note 75 , at 950. 
tion. ${ }^{89}$ Lyons labels as "instrumentalists" those who assert that sourcebased law is not logically sufficient to decide all legal cases-that authoritative legal rules have "gaps." ists and formalists in American legal history divide solely on the question of whether legal rules have "gaps" or "open texture."

\section{Evaluating the Hart-Lyons Model}

The Hart-Lyons account of formalism and instrumentalism nearly succeeds as a model of formalist and instrumentalist legal reasoning. It underscores the function of open texture and warns against the ill effects of denying or exaggerating the extent of gaps in legal rules. In addition, the Hart-Lyons model captures a great deal of the distinction between instrumentalism and formalism as the terms are used in jurisprudence. But if this account is expected to define the formalism/instrumentalism controversy exhaustively, it oversimphifies and mischaracterizes that controversy. In particular, the Hart-Lyons model fails to capture the full force of the realist critique of formalism in at least three ways.

First, it is implausible to think that any broad-based reaction against judicial behavior, like the legal realist movement, could occur simply because of a minor disagreement over the scope of legal rules. As Hart explains, the settled core of a legal rule far exceeds the rule's area of penumbral uncertainty. ${ }^{92}$ Hartian formalists and instrumentalists would thus only disagree over those few "hard cases" 93 falling within the area of open texture. According to the Hart-Lyons model, then, legal realists agreed with formalists about the easy cases; their only complaint was that the formalists misapplied legal rules to hard cases. Yet one central salvo of the realists was that the whole of the law was obsolete-that the formalists applied bad law across the board, not just in hard cases. ${ }^{94}$

Second, the Hart-Lyons model simply cannot explain the link between "conservatism" (however conceived) ${ }^{95}$ and formalism, a link the realists emphasized. Thus Lyons states:

Formalism is often characterized as politically and economically "conservative." It has been associated with judicial decisions that secure the interests of the economically powerful against those who suffer at their hands. The trouble with this interpretation of formalism is that it has no

89. Id. at 952.

90. Id. at $960-66$.

91. Id. at $949-50$.

92. See, e.g., H.L.A. HART, supra note 4, at 124, 148-49.

93. The phrase "hard cases" was coined by Ronald Dworkin. R. DWORKIN, TAKING Rights SERIOUSLY 81 (1977).

94. For the view that formalism and conservatism are related, and for some realist attempts to explain the relationship, see authorities cited infra in note 135.

95. See supra note 9. 
causal connection with the type of theory we have described. . . . What the critics of formalism fail to demonstrate . . . is that formalism is especially related to one side of these battles, or that instrumentalism is especially related to the other side. ${ }^{96}$

Finally, the Hart-Lyons model excludes the possibility of a formalist or instrumentalist method of decisionmaking. If the only difference between a formalist and an instrumentalist is how much open texture each perceives, an instrumentalist attacking formalist legal methods and advancing an instrumentalist legal method appears confused and naive. Lyons postulates an instrumentalist who, when faced with the application of a legal concept in a formalist way, states that in this case the law should be altered to serve useful social goals; that the law should be changed because it does not adequately or properly decide the case at hand. ${ }^{97}$ Although such pleas played a large role in the realist movement-in fact, the movement can be seen as a connected series of themthe Hart-Lyons model makes such pleas seem misguided. When the instrumentalist does not speak of gaps in the law, as an instrumentalist should, he is not being helpful or illuminating:

In sum, if we take the instrumentalist at his word, he is urging the court to ignore existing law and illegally change it. If we take him in some other way suggested by his general position, then we find his comments at best hyperbolic and unilluminating. . . . Very little legal method can be traced to formalistic legal theory. Instrumentalist criticisms of judicial practices seem themselves to suffer from overgeneralization and logical confusion. Furthermore, instrumentalists appear to embrace a naively utilitarian normative theory, and their recommendations concerning judicial legislation are, accordingly, unreliable. ${ }^{98}$

The extent to which the Hart-Lyons model makes nonsense of much of the work of legal realists and legal historians should make one pause before accepting that model. In Part III, this Comment proposes an account that explains the phenomenon of instrumentalist and formalist reasoning styles and makes better sense of what legal realists and legal historians have said about these styles. It will do so by identifying formalist and instrumentalist styles of reasoning and theories of law, and by showing how theories of law can influence judicial reasoning. In so doing, this new account will lead to a better understanding of the importance and limits of the legal realist movement, and a better understanding of the effect of historical scholarship on American judicial reasoning.

96. Lyons, supra note 75 , at 970 .

97. Id. at $970-71$.

98. Id. at 971 . 
III

A Revised Distinction BETWEEN INSTRUMENTALISM AND FORMALISM

This Part will show that the terms formalism and instrumentalism have not only one meaning, but a family of meanings. The task is to discover how the various meanings are related-that is, to see what sort of "family" they comprise. For example, the account will explain why the term "formalist" applies to legal reasoning that is "conservative," as well as to reasoning that stresses deduction. This Comment will argue that there is one primary, central, or "focal" meaning that unifies all of the other meanings of the terms instrumentalist and formalist. In addition, each term has a secondary and a tertiary meaning, each dependent upon or related to the focal or central meaning.

\section{A. The Meaning-in-Use of Formalism and Instrumentalism: $A$ Brief Methodological Discourse}

Though many have tried to formulate a distinction between the terms instrumentalism and formalism, few have commented directly upon the task of formulating such a distinction. What is the appropriate methodology for such a task?

Perhaps the simplest and most straightforward approach is an empirical or pragmatic method. Such a method would discover how people have actually used the terms - with what different meanings and in what different contexts. Professor Summers gives such an empirical ${ }^{99}$ account of these terms by providing a list of features that could be associated with them. One shortcoming of such an approach is that it ignores the possibility of a pattern to various uses of the terms. A purely empirical account will fail to explain why a word is used in only some senses and not in others. An empirical account of the term "white elephant," for example, might discover that it is used to refer to albino pachyderms and to seldom-used objects, but would fail to explain how or why these two meanings are related. Furthermore, such an account will not indicate whether the term is being misused; any use at all will count as one that must be added to the list. In short, a purely empirical account will fail to capture the full meaning of the term and thus fail to capture the term's full conceptual importance.

A second approach is philosophical definition-formulating a philosophically coherent meaning, which then ought to govern use. Under this approach, one searches for a philosophical definition, discarding the philosophically incoherent candidates and selecting the one that appears

99. That is, Summers' method is based largely on the collection of the terms' uses. See R. SUMMERS, supra note 1 , at 157-59. 
to be the "strongest." One then determines whether that "strongest" candidate makes good philosophical sense. Lynda Sharpe Paine, for example, first surveys the uses to which the terms "instrumentalism" and "formalism" are put; having discovered that they are used to refer to both theories of law and styles of judicial reasoning, she then concludes that the reasoning style use is the more "fundamental." 100 She makes the philosophical assumption that a proposed meaning of a term must figure into all the uses of that term in order to be part of the term's philosophical definition. Therefore she rejects fidelity to authority as part of the notion of formalism because some of the uses of the term "formalist" do not involve fidelity to authority. ${ }^{101}$ Moreover, fidelity to authority does not relate in any way to the more fundamental use of the terms as descriptive of the structural features of arguments-in other words, judicial styles. ${ }^{102}$

The philosophical definition approach, however, obscures as much of a meaning of the term as might be revealed by the work it actually does-the tasks to which the term is applied and the way the term is used. Moreover, the methodology of philosophical definition is so divorced from actual use that a philosophical account might end up formulating and analyzing terms no one uses. ${ }^{103}$

The account of the terms "instrumentalism" and "formalism" offered in this Comment is neither a pragmatic description nor a philosophical definition. ${ }^{104}$ It borrows from the pragmatic approach by searching out the actual uses of the terms. It also borrows from the philosophical approach by studying these numerous uses once collected to discover their conceptual coherence and philosophical significance. Yet it differs from both approaches in that it attempts to discern a pattern of use and derive from that pattern the meaning of the term as used. ${ }^{105}$

100. Paine, supra note 27 , at 1000 .

101. Id. at 1000-01.

102. Id. at 1001 .

103. For example, Paine defines formalism as a judicial reasoning style that favors principles and ignores consequences, and instrumentalism as a reasoning style that looks to consequences and ignores principles. Id. at 1000 . A major difficulty with her analysis is that few, if any, legal realists, legal historians, or legal philosophers have ever drawn the distinction as she does.

104. These two definitional approaches provide an illuminating contrast with Wittgenstein's doctrine of meaning in use. In addition, these approaches represent two popular conceptions of how words can be defined or explained.

For a more philosophical treatment of definition of legal terms generally, including a brief discussion of meaning in use, see Hart, Definition and Theory in Jurisprudence, 70 LAW Q. REV. 37, 37. 41 (1954). For a characterization of Hart's method as following Wittgenstein, see Cohen, Symposium: Theory and Definition in Jurisprudence, 29 Proc. ARISTOTELIAN Soc'Y, Supp. 213, 213-16 (1955).

105. This account follows the method suggested in L. Wittgenstein, Philosophical InvesTIGATIONS (G.E.M. Anscombe trans. 2d ed. 1958). Such an approach proceeds under what at first seems a counterintuitive assumption: that people can use a philosophically important concept effectively without "knowing" exactly what that concept means. Specifically, legal scholars may have 
This new account will do very little to change the use of the terms. Indeed, that is not its goal; it aims at discovering, not inventing, the meaning of the terms. This account has a different sort of "payoff"-it will illuminate a term's use and dislodge its hidden assumptions and implications. More specifically, this account will tell us what one means and assumes when he uses the terms "instrumentalist" and "formalist"what those terms imply about those who use them and those to whom they are applied. These insights will aid in assessing the philosophical importance of the terms, and the significance of both the legal realist movement, and historical scholarship relating to judicial reasoning.

\section{B. The Life and Age of Legal Concepts: The Conceptual Foundations of the Distinction Between Instrumentalism and Formalism}

\section{Reasoning by Analogy in Law}

The primary or focal meaning of the terms "instrumentalist" and "formalist" is grounded in the analogical nature of legal reasoning. Reasoning by example plays a central role in legal reasoning. ${ }^{106}$ Professor Levi explains this critical tool of judges:

[Reasoning by example] is a three-step process described by the doctrine of precedent in which a proposition descriptive of the first case is made into a rule of law and then applied to a next similar situation. The steps are these: similarity is seen between cases; next the rule of law inherent in the first case is announced; then the rule of law is made applicable to the second case. ${ }^{107}$

Thus, the heart of the process of reasoning by example is the judge's isolation of the relevant similarity or difference. ${ }^{108}$

While reasoning by example is most obvious in common law adjudication, it also plays a significant role in adjudication under statutes. Two

manifested a sort of understanding of the concept in their use of the concept. Nevertheless, they have not made this understanding explicit. By and large, legal scholars have a practical knowledge of how legal reasoning operates; drawing on this knowledge, they develop terms to classify types of legal reasoning. Their knowledge of a term's meaning is manifested in their use of it. This Comment proposes to give, after the fact, a clear account of the meaning they "use."

This approach might appear less useful when applied to terms-such as those under studythat are used at a theoretical level to reflect upon concrete legal phenomena. One might think that effective theoretical use would require an explicit understanding of the terms. The only defense to such a criticism is to show that the meanings provided explicitly by those who use the tcrms are inadequate, and that on further analysis their use of these terms can be made conceptually coherent. See discussion supra in Part II; discussion infra in Part III, Section B; discussion infra in Part V.

106. See generally H.L.A. HART, supra note 4, at 121-50; E. LEvi, AN INTRODUCTION To Legal Reasoning (1948); N. MacCormick, Legal Reasoning aNd Legal Theory 120-21, 146, 155-56, 159, 187, 190-94, 231-32 (1978); Murray, The Role of Analogy in Legal Reasoning, 29 U.C.L.A. L. REV. 833 (1982). Professor Murray notes that in spite of the importance of analogy in legal reasoning, there is a "dearth" of writing on the subject. Id. at 833.

107. E. LEVI, supra note 106, at 1-2.

108. Id. at 2 . 
features of statutory adjudication explain its reliance on reasoning by example. First of all, the general language of statutes invariably contains enough "open texture" so that hard cases will arise. ${ }^{109}$ The statutory language simply cannot cover all possible cases, and where the statute's applicability is in question, the statute's language serves much the same function as an "authoritative example" in guiding a judge to a proper decision. As H.L.A. Hart explains,

[T] he language of the rule seems now only to mark out an authoritative example, namely that constituted by the plain case. This may be used in much the same way as a precedent, though the language of the rule will limit the features demanding attention both more permanently and more closely than precedent does. Faced with the question whether [a] rule prohibiting the use of vehicles in the park is applicable to some combination of circumstances in which it appears indeterminate, all that the person called upon to answer can do is to consider (as does one who makes use of a precedent) whether the present case resembles the plain case "sufficiently" in "relevant" respects. ${ }^{110}$

A second feature of statutory adjudication also makes argument by example important. In interpreting a statute, a judge must often attempt to discern the legislature's intent. The judge must try to pick out the aspect of the case that the legislators would have thought relevant by analogy to the model or central case described by the statute. ${ }^{111}$

Reasoning by analogy in either common law or statutory adjudications produces an apparent evolution of legal concepts from one historical moment to the next. A single judicial concept developed through reasoning by example will come into existence, attain prominence, and then gradually pass away.

\section{The Birth, Life, and Aging of a Concept}

Analogically created legal concepts and the rules that encapsulate them ${ }^{112}$ arise through the use of key words to classify or name relevant similarities or differences. The lack of a ready word to express similarity or difference might at times "prevent change in the law," but when soci-

109. See supra text accompanying notes 76-81 (discussing open texture).

110. H.L.A. HART, supra note 4, at 124. In relying on Hart's explanation of the relation between the role of analogy in legal reasoning and open texture, it is not necessary to accept Hart's explanation for why there is "open texture" in legal rules. In fact, Hart's view that the vagueness of classificatory terms itself leads to the vagueness of legal rules seems at the very least to be incomplete. On the sense in which human activities "go beyond" precepts that self-reflectively describe these activities, compare Aristotle, supra note 29, Book I, at 1137b10-33; Plato, Statesman 294a-c (J.B. Skemp trans.), in The Collected Dialogues of Plato (E. Hamilton \& H. Cairns eds. 1961); and P. Winch, The IdeA OF A Social SCIENCE 51-57 (1958).

111. E. LEVI, supra note 106, at 6-7.

112. As used in this Comment, the term "rule" signifies a statement of all or part of a legal doctrine. The term "concept" signifies a single legal idea that can be embodied in a rule or rules. 
ety has begun to see a significant similarity or difference, "the comparison emerges with a word." 113 Legal concepts are thus "born" when a court or courts begin to compare an initial set of cases and to fumble for an appropriate word or phrase to encapsulate a particular relevant similarity or difference. After a satisfactory or appealing word or phrase has been found, "the concept is more or less fixed, although reasoning by example continues to classify items inside and outside of the concept."114 It is at this stage of a legal concept's life that the concept most completely exercises a limiting infiuence-so much so that the reasoning in legal cases arising under the concept may seem completely deductive. ${ }^{115}$ This is because the established formulations of the concept, usually as a legal rule, encapsulate a similarity or difference so obviously relevant to judges that legal reasoning consists of asserting the legal rule (as a major premise), stating the presence of the relevant similarity or difference (as a minor premise), and deducing the holding of the case.

At some point, however, cases that are no longer sensibly or coherently classifiable by this reigning concept will begin to arise, and the concept will begin to "break down," or "die." Eventually this old concept will be rejected and replaced with a new concept. ${ }^{116}$ Legal concepts, then, have an infancy, a maturity, and an old age.

There are at least three ways in which a legal concept can "age." A concept is applicable to certain cases because the cases manifest some relevant similarity or difference. First, suppose that new cases uniformly manifest a certain additional factual pattern suggesting a new relevant similarity or difference and therefore a new analogy. In other words, the new cases have materially different facts. When this happens, the controlling analogy will begin to age-its usefulness is limited to those cases without the new set of facts. The fewer cases that represent the old factual pattern, the older the concept becomes. ${ }^{117}$

Second, a concept might "age" if the factual assumptions upon

113. E. LEV1, supra note 106 , at 8.

114. Id. at 9.

115. Id. at 8.

116. Id. at'9. For a similar account, complicated for purposes of showing the "incremental quality" of the change of analogically developed rules, see N. MACCORM1CK, supra note 106, at 160, 225, 237-38.

117. Rowland v. Christian, 69 Cal. 2d 108, 443 P.2d 560, 70 Cal. Rptr. 97 (1968), illustrates the many ways in which concepts age. In Rowland, the social guest of a tenant was injured when the handle of a water faucet broke, and the guest brought a personal injury action against the tenant. The California Supreme Court reversed the lower court's grant of summary judgment for the defendant, holding that the proper test for liability was whether the tenant of the property acted with reasonable care in view of the possible injury to others. Id. at 119-20, 443 P.2d at 568-69, 70 Cal. Rptr. at 104-05. Prior to Rowland, California followed the traditional common law rule that the standard of care owed by an occupier was conditioned on the class to which the injured individual belonged. The occupier owed to "invitees"- those entering the premises for business purposes and remaining on the premises for reasons relating to that purpose-a duty of ordinary or reasonable 
which the analogy is based become more and more suspect as time passes. The less sound these factual assumptions are, the less relevant the relevant similarity or difference; undermining an old factual assumption reveals that the facts of current cases are different in a significant way from the facts of the cases to which the concept originally applied. ${ }^{118}$

A third way in which a concept might age is if the value or policy assumptions governing the selection of the relevant similarity or difference are called into question. As these assumptions become less convincing, or convincing in fewer of the cases that the concept decides, the concept becomes "older." 119

\section{Does the Phenomenon of Aging Indicate that Legal Cases Do or Do Not Have a Right Answer?}

The phenomenon of the "aging" of legal concepts raises a question about the nature of such concepts. Do concepts have a certain period during which they are objectively or normatively "correct"-in which they describe how the law is or how it should be-and afterwards a period in which they are "incorrect"? Or does the age, and therefore the correctness, of a legal concept depend on the opinions of particular judges, or more generally the opinions prevalent in a particular historical era? Perhaps legal concepts only appear to most jurists to "age," whereas in fact aging is a subjective, conventional phenomenon.

For purposes of the relationship between formalism and instrumentalism, it does not matter whether concepts really age or are simply thought by jurists to age. It is the appearance of aging that creates the concepts of instrumentalism and formalism; it is unnecessary to decide whether recognizing the phenomenon of aging is indicative of an underlying jural reality. Age is a phenomenon that must be accounted for, and is accounted for, in any of a variety of ways by different philosophies of law, but any sound jurisprudence must begin with the realization that concepts age.

care, whereas he owed to social guests or trespassers only a duty to refrain from recklessness. Id. at 113-14, 443 P.2d at 565, 70 Cal. Rptr. at 101.

A portion of the majority opinion illustrates how concepts are said to age when a new relevant similarity or difference emerges. Justice Peters argued that whereas the existing rule looked to economie and individual relationships and duties in a feudal society, a new relevant factor had emerged-complex interrelationships, economic and otherwise, of the modern industrialized world. Id. at 116, 443 P.2d at 566, 70 Cal. Rptr. at 102 (relying on Kermarec v. Compagnie Generale, 358 U.S. $625,630-31$ (1959)).

118. For example, Justice Peters argued in Rowland v. Christian that the complex feudal relationships upon which the rule was based no longer exist. Id. at $113,443 \mathrm{P} .2 \mathrm{~d}$ at 564-65, $70 \mathrm{Cal}$. Rptr. at 100-01.

119. For example, Justice Peters strongly implied that the traditional rule of occupier liability was not in harmony with a change in social values-an increasing regard for human safety. Id. at 114,443 P.2d at 565, 70 Cal. Rptr. at 101 . 
It may seem at first that the idea that concepts age implies that cases can never have an absolutely right answer, but only a relatively right answer-an answer that is completely dependent on place and time. For example, Hart's model, which allows for the aging of legal concepts, suggests that whoever posits the law authoritatively determines the exact scope and content of such concepts and thus subjectively determines the course of the aging process. In other words, Hart thinks that concepts age not necessarily because they actually become out of date, but because the legal actor with the authority to interpret the law has decided that they ought to change. ${ }^{120}$ Hart thus accounts for aging without conceding that aging is an objective phenomenon.

On the other hand, Professor Ronald Dworkin recognizes the phenomenon of aging and seeks to account for it in a way that will preserve the position that there can be right answers in every case, even in the hard cases that sometimes give rise to new legal concepts. According to Dworkin, the assertion that there are no right answers in hard cases ignores the distinction between broad moral or legal/moral "concepts," such as fairness or equal protection, and a particular "conception" of a "concept" embodied in a particular moral or legal rule. ${ }^{121}$ Dworkin illustrates the distinction with a hypothetical: if he were to tell his children to treat others "fairly," he would have in mind some specific examples of fairness. Dworkin asserts that what he means by fairness (his "concept") is not limited to those particular examples (embodying "conceptions") but extends to various other examples that he did not consider, or that he considered, rejected, but later changed his mind about and accepted. ${ }^{122}$ Analogously, a court trying to decide a hard case by formulating a new legal rule is bound to interpret the "concept" embodied in that rule by looking at particular "conceptions" that purport to substantiate that concept. A judge must make a guess about what the "concept" means in a particular context. ${ }^{123}$

Without Dworkin's assertion that conceptions are linked together by concepts, the idea of a "right answer" in hard cases would vanish. ${ }^{124}$ For present purposes, it is important to realize that it is possible to inter-

120. For a discussion of the positive foundations of legal validity, see generally H.L.A. HART, supra note 4, at 97-120; for a discussion of the discretion involved in judicial decisions in the open texture of the law, see $i d$. at $128,138-44$.

121. R. DworkIN, supra note 93 , at 134-36.

122. Id. at 134.

123. See id. at 101-05.

124. This is so because a court's duty to provide a right answer arises from the nature of the judiciary (or perhaps of the legal system as a whole) as an autonomous institution. According to Dworkin, a principle of fair play of some sort makes the rules of the institution binding. See id. at 105-06. Thus in adjudicating disputes arising under rules embodying essentially contested concepts, a court must elaborate concepts by supplying the best available conception of those concepts. Id. at 132-37. 
pret the phenomenon of aging in various ways. Merely recognizing that there is such a phenomenon does not commit one to any position as to whether legal issues have a right answer.

\section{The Family of Meanings}

\section{The Primary or Focal Meaning of the Terms "Instrumentalist" and "Formalist"}

Once the "aging" of legal concepts is explained, it is possible to set forth the focal meaning of the terms "instrumentalist" and "formalist." ${ }^{125}$ First, it is important to note that judges and other legal actors often make subjective assessments about a particular concept's age. Yet, to assess the age of a legal concept is to take a position on the empirical, methodological, and value assumptions upon which a particular concept rests. This is so because a concept's "age" is a function of the continuing vitality of these assumptions. Whenever an actor uses the term "formalist" or labels a concept "too old" or "too young," he is making a substantive assessment of the soundness of the concept's basic assumptions.

Disagreements over the age of a particular legal concept or rule provide a good starting point for elucidating the primary or focal meaning. Suppose a particular legal actor Alpha feels that a particular concept $X$ has outlived its usefulness. For example, Alpha may think that the facts of new cases now present courts with a new relevant similarity or difference, that the old factual assumptions should be challenged or discarded, or that in some way the value assumptions underlying the concept are outdated. Alpha feels, in other words, that the concept is functionally dead.

Suppose that another legal actor Beta disagrees with Alpha about the age of concept $X$. Beta feels that the concept is still useful, still young. Beta would remark that legal actor Alpha wants to discard the concept too quickly, for Beta thinks that the concept in question still has vitality. Beta could call Alpha an "instrumentahist" with reference to legal concept $X$. Similarly, Alpha could accuse Beta of using a dead or nearly dead concept: Beta, according to Alpha, is a "formahst." The actors are using the terms instrumentalist and formalist in their focal or primary sense.

In this example, both actors have made independent substantive assessments of the current state of the law and of the need for a change in the controlling legal concept. A legal actor assessing the age of a concept

125. The full sense in which the term "focal meaning" is intended is explained in the text. For a more complete discussion of a developed doctrine of focal meaning, see the discussion of Aristotle's doctrine of "equivocals" in J. OWENS, THE DOCTRINE OF BEING IN THE ARISTOTELIAN Metaphysics 107-31 (1951). 
necessarily makes a substantive assessment of the concept's continuing efficacy in resolving cases. This element of the age-assessing process will be referred to as the "substantively assessing feature" of the terms instrumentalism and formalism.

Finally, it is important to note that the terms formalist and instrumentalist will not usually be used in this primary sense. If two legal actors Alpha and Beta disagree over the age of a legal concept they will rarely hurl at each other the epithet formalist or instrumentalist-they are much more likely to argue about the merits of the case directly. Alpha is much more likely to simply argue with Beta about what the right legal concept is, without referring to the age of the concept in question. ${ }^{126}$

\section{The Secondary Meanings of the Terms Formalist and Instrumentalist}

The secondary sense of the terms instrumentalist and formalist emerges when a pattern of using concepts that are either too old or too young emerges. If a legal actor is judged to make habitually formalist legal analogies, the individual making this judgment would call this actor "formalist" in a secondary sense. (There is, of course, a corresponding secondary sense to the term instrumentalist.)

This secondary sense retains the substantively assessing feature of the primary sense of the terms. Of course, it will be harder to justify a charge of formalism or instrumentalism in the secondary sense because the person making the charge must have made conclusions about the concept's applicability to a number of different cases. The charge goes beyond these cases, however, to point out a pattern of using only old or only young concepts, and hence isolates a formalist or instrumentalist reasoning style.

This secondary sense is dependent on the primary sense. The notion of habitually using concepts either too old or too young rests on the notion of using in a single case a concept that is too old or too young. For this reason, the terms are more likely to be used in their secondary sense. Whereas a single instance of formalist (in the primary sense) judicial reasoning does not generally warrant drawing attention to the age of the concept at issue, the assertion that a legal actor repeatedly defends con-

126. The terms "instrumentalist" and "formalist" are tied to the ordinary meanings of the terms "instrumental" and "formal." "Instrumentalist" refers to one who refuses to apply an existing legal concept as currently formulated and who instead uses it as an instrument to accomplish some aim unrelated to that concept. "Formalist" refers to one who uses a concept that has lost its vitality, its substantive applicability to current fact situations. Only the form of sound legal reasoning remains, because its substance has perished. 
cepts that are too old may be a jurisprudential phenomenon worth attention.

Such behavior seems to indicate a pattern of decisionmaking independent of that actor's view on the merits of particular cases. It suggests that something other than the actor's views on the inerits is guiding his or her decisions-that for one reason or another, the actor is deliberately using old concepts. Such usage of concepts could be characterized as a formalist reasoning style. Thus whenever a legal actor systematically uses concepts of a certain age, he can be characterized as an instruinentalist or a formalist. This secondary sense, then, refers to styles of judicial reasoning.

\section{The Tertiary Meaning of the Terms "Formalism" and "Instrumentalism"}

The tertiary sense of the terms "instrumentalism" and "formalisin" arises out of a need to explain the existence and the cause of instrumentalist and formalist reasoning styles. The tertiary sense relates these judicial reasoning styles to any of a number of theories of law. Suppose that Alpha has decided that Beta is a formalist in the secondary sense. Alpha unight then try to discover why it is that Beta's decisions are consistently formalist-why it is that relative to Alpha's own substantive assessment of the current state of the law, Beta tends to overextend the life of legal concepts. Alpha must ask himself what views Beta holds that cause Beta to reason in a formalist way. Somehow Beta's unstated views are served by preserving extant legal concepts. Alpha could discover that Beta has unstated views not about the merits of the cases in particular, but about the nature of adjudication in general, the role of judges in the legal system, or the nature of law itself. These views explain why Beta clings to "old" concepts.

Alpha will claim that Beta acts in a formalist way not because of his opinions on the merits of a case, or on a particular concept or group of concepts, but because he holds views independent of these opinions. One can reasonably say that for Beta, being formalist as such is a goal of judicial reasoning. Thus if Beta adheres to a strict doctrine of precedent or sees legal doctrines to be the embodiment of God's law and therefore sacrosanct, Beta will be formalist because using only existing legal concepts serves his goal of preserving God's law.

This tertiary use of the terms formalist and instrumentalist refers to theories of law that cause a legal actor to be formahist or instrumentalist in the secondary sense. There is no one particular theory responding to either of these names-any theory about the nature of law or adjudication that produces formalist or instruinentalist judicial reasoning can be called a formalism or an instrumentalism. These tertiary terms retain the 
substantively assessing feature of the primary and secondary senses. Thus, tertiary formalism or instrumentalism exist only when at some point a legal actor shows that legal concepts are being ushered in or out too early, too late, or at just the right times in their "lives" to provide correct resolutions of legal issues. ${ }^{127}$

To summarize, the primary or focal meaning of formalist and instrumentalist refers to a decision in a particular case, the secondary meaning refers to a judicial reasoning style, and the tertiary meaning refers to any theory of law that causes a legal actor to adopt a formalist or instrumentalist reasoning style.

IV

\section{The HART-Lyons MODEL Revisited}

These three related meanings account for the varied uses to which the terms have been put by historians, legal realists, and philosophers. Before applying the focal familial account to these uses of the terms, it is instructive to compare this account with the Hart-Lyons model. As shown in Part II, ${ }^{128}$ Hart argues that the indeterminacy of general classificatory terms produces the phenomenon of indeterminate legal rulesrules with open texture. Open texture allows legal actors discretion to choose among possible applications of the rule after it has been formulated or adopted. The indeterminacy of the rule's meaning enables one to ascribe different purposes to the rule or to tailor its application to shifting factual situations. Although Hart's jurisprudence of formalism and rule skepticism can provide an illuminating description of the "life" of a legal concept in terms of open texture, such a description has serious shortcomings: it can neither distinguish between "live" and "dead" concepts nor explain shifts from one reasoning style to another.

Throughout their lives, legal rules have areas of open texture, which according to Hart, judges must be able to recognize and use on a case-bycase basis with enlightened, conscious discretion. But legal rules also

127. It should be noted that the term "formalist" in the secondary or tertiary sense is often used in a pejorative sense-referring to a style of reasoning (and corresponding theories of law) tending to use concepts that are too old. Usually, instrumentalism is not used in a correspondingly pejorative sense to refer to a style of reasoning that uses concepts which are too young, and to corresponding theories of law that produce such a style. The term instrumentalism is usually used either in a neutral or a complimentary sense. In the neutral sense, the term refers to a style of reasoning (and corresponding theories of law) tending to use concepts that are young. The complimentary sense adds the judgment that this use of young concepts, whcre engaged in, is appropriate.

Because this feature of the use of the terms does not illuminate the meanings of the terms under study and results entirely from historical accident (such as the fact that the realists and their follow. ers, who were to our "enlightened" eyes instrumentalists in a complimentary sense, first put the terms to work in legal analysis), this Comment has not addressed this feature of the use of these terms.

128. See supra text accompanying notes $76-85$. 
have an apparent lifespan, a limited period during which the factual, social, political, or moral premises upon which the settled core of the rule rests appear to remain viable. Therefore a judge cannot adequately apply legal rules by simply legislating interstitially whenever an area of open texture arises. The problem is not how to apply the concept of "vehicle" to the penumbral case of toy cars, but rather whether the very concept of vehicles, or the entire rule barring vehicles which incorporates the concept, should be changed. For example, suppose that the park in Hart's example is fenced off entirely and stocked with wild animals and thereby converted into a wild animal park. When a judge is faced with the question whether a particular type of automobile is to be prohibited from the park, he is not worried about whether the automobile constitutes a vehicle. $\mathrm{He}$ is more concerned about whether in light of changed factual circumstances, the settled core of the rule needs to be replaced with a new core, because the very purpose of the wild animal park is to allow people to drive through it to view the animals. A judge must develop the ability to recognize the death of a concept.

In describing formalism and rule skepticism, Hart is not interested in how legal rules are born and die, but only with their lifespan or aging. But such "core changes" are essential to an account of formalism and instrumentalism, and therefore Hart's model of formalism and rule skepticism is of limited utility. This emphasis on the concepts of life and death is only a limited criticism of Hart. Hart would recognize that at times judges legislate new rules into existence when a rule appears to lose its settled core of meaning. The new emphasis only suggests that the idea of the age of legal concepts and the particular judicial talent of sizing up the age of such concepts should be made explicit and incorporated into a complete account of the terms formalist and instrumentalist.

The Hart-Lyons model suffers from a second shortcoming-it provides no detailed explanation of the close historical and logical relationship between periods of formalism and periods of rule skepticism. As explained above, ${ }^{129}$ the Hartian vice of rule skepticism exhibited by some of the legal realists consists of denying entirely that legal rules have settled core areas. Hart does not explain how or why the overreaction of legal realists to formalism produced rule skepticism. Hart simply states that the two vices are opposing tendencies in American judicial thought, implying that some sort of pendulum effect explains this overreaction. ${ }^{130}$

But the focal familial account of formalism and instrumentalism clearly explains the historical link between formalism and rule skepti-

129. See supra text accompanying notes $82-85$.

130. Hart developed his descriptions of formalism and rule skepticism to illuminate his account of the open texture and settled core of legal rules. Thus, it is not surprising that his account fails to capture completely the historical phenomena of formalism and rule skepticism. 
cism. Critics who level the charge of "formalist" will tend to observe that there is very little settled area to law-the settled core to the rule is, for them, gone. This leaves no settled area to the rule at all, but only an empty conceptual exercise. For example, this conceptual exercise is embodied in an attempt to apply the rule forbidding vehicles to automobiles, regardless of how senseless this may seem in the case of a wild animal park. A rule skeptic urges in general what the critic of formalism urges with reference to particular legal concepts: that legal rules have no core. The loss of the core of the rule that occurs as a rule ages explains the historical correlation between charges of formalism and the prevalence of rule skepticism: rule skepticism is skepticism about whether legal rules have a settled core, and thus will tend to arise during a period of reaction against formalist judicial reasoning, which is perceived to apply coreless legal rules.

\section{$\mathrm{V}$}

\section{APPLYING THE Focal FAMILIAL AcCoUnT}

The focal familial account of the meaning of formalism and instrumentalism illuminates the legal realist critique of formalism. In addition, this account illuminates the work of legal historians on judicial reasoning styles in American history.

\section{A. The Application to Legal Realism}

The focal familial model of formalism and instrumentalism fares well when applied to the legal realists. The realists often directly attacked legal concepts as outmoded or outdated, manifesting an understanding that formalist reasoning misjudges the age of legal concepts. ${ }^{131}$ Moreover, the more astute of the realists recognized the substantively assessing aspect of the charge of formalist and endeavored to establish that legal concepts in use were objectively out of date in their application to specific cases. ${ }^{132}$ Still other legal realists struggled to explain why judicial reasoning had become formalist in the secondary sense, searching out theories of law that might cause formalist reasoning and could therefore be grouped together under the label of formalism. ${ }^{133}$

The theories that the realists espoused as part of their positive pro-

131. For examples of the tenor of the legal realists' attack on formalism, see Oliphant, supra note 1; Pound, Mechanical Jurisprudence, 8 ColUM. L. REv. 605 (1908) [hereinafter cited as Pound, Mechanical Jurisprudence]; Pound, The Theory of Judicial Decision (pts. 1-3), 36 HARv. L. REv. $641,802,940$ (1923).

132. See Pound, Mechanical Jurisprudence, supra note 131, at 606-08, 611, 614.

133. See, e.g., Oliphant, supra note 1. Oliphant focuses on the out-of-date character of prevailing law. He attempts to show that a gradual expansion of legal concepts had made the law of his time outmoded and that, ironically, this expansion was the result of judicial efforts to cope with a rapidly changing world. 
gram, such as awareness of the social operation of law in action, or a belief in the narrow construction of precedents, served to make legal realist judicial reasoning more instrumentalist in the secondary sense. Thus, these doctrines could be called instrumentalist in the tertiary sense. The legal realist criticism of formalist jurisprudence was more than a limited attack on judicial behavior in the penumbral area of common and statutory law. Rather, it focused on a purported formalist tendency to keep concepts alive beyond their years. The legal realists' proposed study of the law in action would test empirical and methodological assumptions underlying legal rules and thus assure that the old concepts were promptly discarded. ${ }^{134}$

The focal familial account also explains the charge that the formalists advanced outmoded legal theories and were "conservative" in their legal views. The Hart-Lyons model dismissed this portion of the legal realist attack on formalism as confused. But the heart of the charge of "formalism" was the substantive assessment that the law was out of date, and that judges were conservative in sticking to existing doctrines that were then in place, simply because they already existed. ${ }^{135}$ In fact, the

134. See supra text accompanying notes 14-19.

135. Llewellyn states that a realistic approach to dividing observations into legal categories "rests on the observation that categories and concepts, once formulated and once they have entered into thought processes, tend to take on an appearance of solidity, reality and inherent value which has no foundation in experience." Llewellyn, Realistic Jurisprudence, supra note 1, at 453 . This is true even though those concepts were "originally formulated on the model of at least some observed data." Id. The problem is that these concepts tend "to suggest the presence of corresponding data when these data are not in fact present, and to twist any fresh observation of data into conformity with the terms of the categories." Id. The solution for Llewellyn, and for the realist movement generally, was to determine whether the data were still present in the form suggested by the concept, by studying the "law in action." See id. at 454,460 \& n.31; see also J. FRANK, supra note 1, at 270 77 (endorsing Oliver Wendell Holmes' assertion that the law needs constant updating via judicial legislation because of constantly changing social circumstances); id. at 111, 125, 156, 164 n.5 (describing the judicial "hunch" as a modernizing tool for judges); Cohen, Process of Judicial Legislation, in Readings in Jurisprudence and Legal Philosophy 121-24 (M. Cohen \& F. Cohen eds. 1952) (asserting that since "life is continually developing new and unforseeable situations not covered by precedent, . . . it follows [that judges] must in the course of their work develop new rules"); id. (stating that the extent of a rule's open texture is a function of the "rapidity with which conditions of life are changing"); Llewellyn, Realism, supra note 1, at 1250-53 (Llewellyn's discussion of stare decisis as a way of changing law to keep pace with changes in society); Llewellyn, Realistic Jurisprudence, supra note 1, at $454 \mathrm{n.22}$ (citing authorities to studies of the law in action).

A particularly clear treatment of the aging of certain legal rules and concepts is found in Oliphant, supra note 1 , at 73-74, 76. Oliphant explicitly describes how the abstractions upon which Anglo-American common law was built had become out of date. First, the relevant legal concepts were born; thereafter, they remained viable for a long period:

For great stretches of time there were few fundamental changes in the structure and operation of English domestic, industrial, and political life. Abstractions once made fitted longer. Corresponding rules of law asserting this or that about them, however abstract in phrasing, related, in actual operation, to fact situations to which they had not become alien. The resulting social control better fitted current needs.

Id. at 74. But as rapid social change occurred, these groupings became "more and more antiquated 
efficacy of the entire legal realist attack depended on the extent to which the realists' substantive assessments were accurate.

In addition, this account makes sense of a plea of the legal realists that the Hart-Lyons model describes as confused-the plea that the law be altered to serve useful social goals or to reach the right result in a particular case. ${ }^{136}$ Far from being hyperbolic and unilluminating, this plea is in fact the heart of an instrumentalist program, for it points out the purported substantive inefficacy of the black-letter law.

The new account also explains why the legal realist platform was the exact negation of formalist jurisprudence as the realists described it. The two chief tenets of formalism that the realists decried-deductivism and conservatism-were causes of reasoning that was formalist in the secondary sense, that habitually relied on old concepts. ${ }^{137}$ The realists proposed exactly what was needed to counter this tertiary formalism that had made the law out of date: theories of law and adjudication that would result in instrumentalist legal reasoning. Deemphasis on logical deduction and emphasis on law as an instrument of social change promoted the continual updating of all old legal rules and thus constituted a tertiary instrumentalism to counter and negate the tertiary formalism of the nineteenth century.

\section{B. Application to Legal Historians}

The focal familial account of instrumentalism and formalism also sheds some light on the failures of legal liistorians to isolate a particular formalist or instrumentalist style of judicial reasoning. A charge of formalism in the tertiary sense can only be made by establishing that the law in a particular area is out of date. This is because tertiary formalism is only an explanation for formalist (in the secondary sense) reasoning revealed by numerous instances of formalist (in the primary sense) analogy.

by the shift in patterns of life." Thus "[o]ur categories of thought have become unreal by life having left them behind . . . ."Id. at 76. A quite similar account is put forth by Roscoe Pound:

In periods of legal development through juristic speculation and judicial decision, we have a jurisprndence of ends in fact, even if in form it is a jurisprudence of conceptions. . . . [For example, the] development of equity in England was attained by a method of seeking results in concrete causes. . . . Whenever such a period has come to an end, when its work has been done and its legal theories have come to maturity, the jurisprudence of conceptions tends to decay. Conceptions are fixed. The premises are no longer to be examined. Everything is reduced to simple deduction from them. Principles cease to have importancc. The law becomes a body of rules. This is the condition against which sociologists now protest, and protest rightly.

Pound, Mechanical Jurisprudence, supra note 131, at 611-12. Pound manifests an implicit understanding of the substantively assessing feature of the term formalist by giving specific examples of ways the law was out of date. Id. at 614-21.

136. See supra text accompanying note 97 .

137. See supra text accompanying notes 21-22. 
Unless they show the law to be out of date, these historians are left in pursuit of a chimera.

Horwitz and Nelson can never properly find a rise in instrumentalist or formalist judicial reasoning until they have assessed the extent to which an area of the law was ripe for change at a given point in history. Only after such an assessment can a historian assert that a given judge was a formalist or an instrumentalist. The new account of these terms suggests that substantive normative assessments, though unarticulated, underlie the work of these historians.

Nelson's and Horwitz's accounts of strict doctrines of precedent serve as examples. ${ }^{138}$ Whenever Horwitz and Nelson label a judge a formalist because of his adherence to precedent, they imply that the substantive law the judge applied was becoming, or had become, out of date. For only when a rule or concept reaches its twilight years does the normal judicial process of reasoning by example begin to appear unusually rigid. When the rule is old, the formerly relevant similarity or difference has become irrelevant. Yet formalist judges will continue to apply the rule to the new cases mechanically, even after the passage of time has drained all life from it. Only when the rule is old will adherence to precedent merit notice. There is nothing particularly striking about stare decisis when legal rules are in their prime, because stare decisis then coincides with sound reasoning. It is only when recent developments suggest a change in the rule that a judge will appear rigid in his adherence to precedent.

The difficulty Nelson and Horwitz have in pinning down formalism and instrumentalism is that neither writer keeps in mind this substantively assessing feature of the terms. Neither author actually demonstrates that judges in fact made use of outdated legal concepts; therefore the charge of formalist or instrumentalist legal reasoning, and derivatively of formalist or instrumentalist legal theory, vanishes. The other features of formalism that Horwitz and Nelson take pains to point out, such as commitments to a strict doctrine of precedent, to excessive use of logical deduction, and to higher law, are only meaningful to the extent that they explain an already documented formalist reasoning style. These theories are only formalist in the tertiary sense when they explain why judges are using outmoded legal concepts. Horwitz and Nelson appear to be trying to make complex historical-legal judgments about the appropriateness of a particular concept for a particular time and place. The improved formalism/instrumentalism distinction presented in this Comment reveals the intricacy and ambitiousness of their project, as well as the shortcomings of their execution of it.

138. Horwitz, supra note 3, at 297-98, passim; Nelson, supra note 3, at 514-15, passim. 
Another legal scholar makes a similar historical claim but exemplifies a more sophisticated use of the terms. Professor Charles McCurdy argues against a particular doctrine of Justice Field in the area of government jurisprudence, the doctrine that the public and private domains of government can be separated by using the long-established eminent domain concepts of public purpose, inalienability, and just compensation for public use of private property. ${ }^{139}$ McCurdy claims, in effect, that Field was a formalist in the primary sense with respect to each of these related doctrines, that his continuing use of these doctrines amounted to a secondary formalism, and that he espoused a theory of law that tended to make his reasoning on certain issues formalist. Thus McCurdy argues that

[in Field's] view, the need to formulate universal rules determining the legitimate range of public interventions in economic life took precedence over the immediate consequences his position involved, even if it entailed the exploitation of local governments by railroad corporations or irreparable damages to bondholders. For Field, once the character of the use had been fixed, it was immutable and applied to all governmental interventions. ${ }^{140}$

As argued above, McCurdy's charge will stick only if it is based on the assumption that Field's doctrines are out of date. And indeed, the thrust of McCurdy's article is to show that the doctrines Field developed were obsolete by the time they came to fruition:

But Field's "immortal truths," if viable at all, provided solutions only for the policy issues of the 1870 's. . . . Field's government-business jurisprudence perished, however, not because it had been internally incosistent [sic] or had failed to reflect the ideological commitments of postCivil War Americans, but because his doctrinal system proved to be incongruent with the rapidly changing needs of an ever-expanding capitalist society. ${ }^{141}$

Thus McCurdy presents a fully coherent use of the formalist half of the

139. McCurdy, Justice Field and the Jurisprudence of Government-Business Relations: Some Parameters of Laissez Faire Constitutionalism, 1863-1897, in AMER1CAN LAW AND THE CONSTITUTIONAl ORder: Historical. Perspectives 246 (L. Friedman \& H. Scheiber eds. 1978).

140. Id. at 254 .

141. Id. at 265. The argument alluded to in the text is but a small part of McCurdy's larger endeavor to revise the current understanding of Justice Field's government-business jurisprudence, as "cut from the same bolt of cloth" as William G. Sumner's Social Darwinism, or as a product of "the Gilded Age with its Great Barbecue for the Robber Barons and for the rest." See id. at 246.47. McCurdy is responding to, inter alia, works of two historians, R. MCCloskey, AMERICAN CONSERVATISM IN THE AGE OF ENTERPRISE 103 (1951), and Mendelson, Mr. Justice Field and LaissezFaire, 36 VA. L. REV. 45, 55 (1950). McCurdy seeks to show that "Field shaped his governmentbusiness jurisprudence to provide 'final' solutions to the many-faceted, 'great underlying problem' of the 1870's: government's legitimate role in economic life," and that the jurisprudential product was an "extraordinarily consistent" set of legal doctrines. McCurdy, supra note 139, at 247. The portion of McCurdy's article relevant here faults Field's doctrines only because they were outmoded by the time that they had come to fruition. Id. at 265 . 
formalism/instrumentalism distinction. McCurdy explains why Field's reasoning style was formalist in the secondary sense: Field used outmoded legal doctrines in the areas of law in question. McCurdy thus keeps clearly in mind the substantively assessing feature of the secondary sense of the term formalist. He then establishes a link between a formalist theory of law (natural law) and formalist reasoning by blaming Field's commitment to the doctrine of natural law for the fact that Field's doctrines became outmoded. Without setting forth an account of the meaning of formalism, McCurdy has fully illustrated the correct use of this term.

\section{CONCLUSION}

Although formulating a workable distinction between formalism and instrumentalism as theories of law or as styles of judicial reasoning may be difficult, such a distinction in either form seems quite tenable. The focal familial account developed in this Comment avoids the difficulties of earlier formulations of the distinction and is more complete than the model developed by Hart and Lyons. The account makes sense of both the legal realists' critique of nineteenth-century formalism and their own positive program for improving judicial reasoning, as well as illuminating the recent historical scholarship relating to styles of judicial reasoning in American history.

Steven M. Quevedo*

* A.B. 1982, Princeton University; third-year student and graduate student in Jurisprudence and Social Policy, Boalt Hall School of Law, University of California, Berkeley. 